\title{
HUMAN RESOURCE DEVELOPMENT IN AIRLINE INDUSTRY: A STUDY ON HRD INITIATIVES OF INDIAN
}

\author{
Joby Thomas* and Prof. P. Pakkeerappa**
}

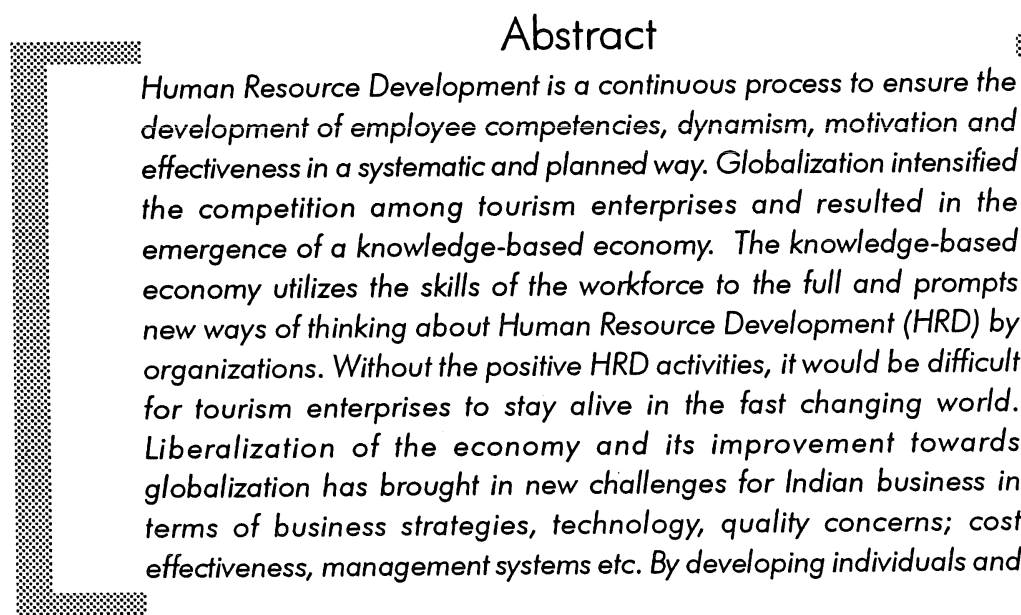

* Lecturer, Department of Tourism Studies, Christ College, Bangalore,

** Professor \& Former Dean, Dept. of Business Administration, Mangalore University, Mangalagangotri, Karnataka. 


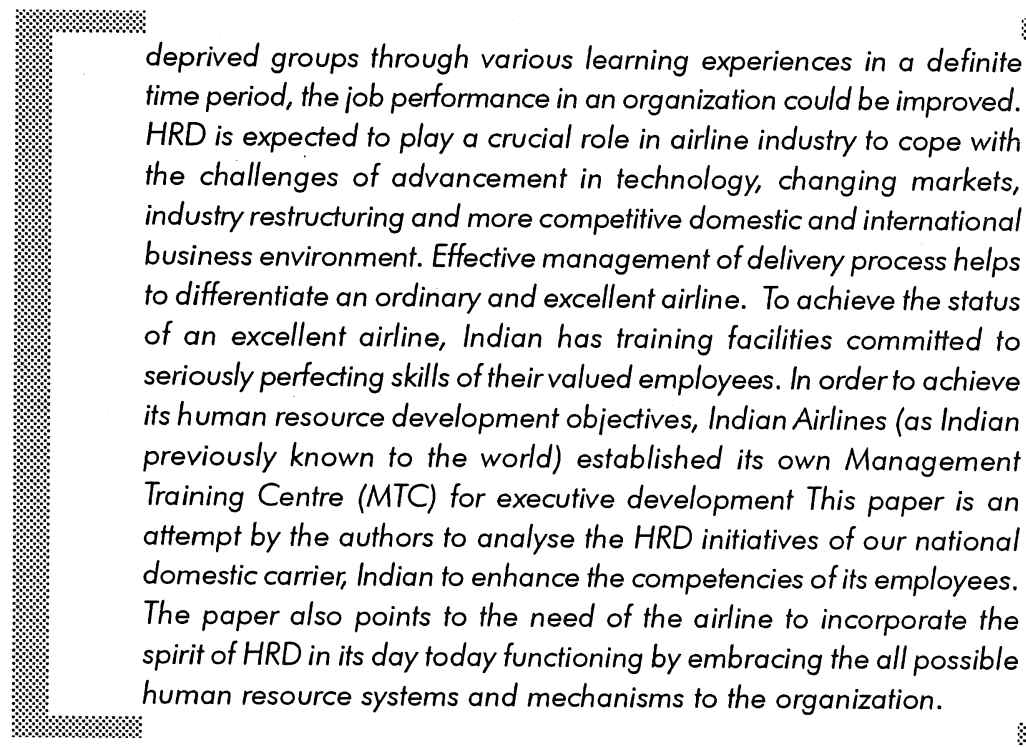
time period, the job performance in an organization could be improved. $H R D$ is expected to play a crucial role in airline industry to cope with the challenges of advancement in technology, changing markets, industry restructuring and more competitive domestic and international business environment. Effective management of delivery process helps to differentiate an ordinary and excellent airline. To achieve the status of an excellent airline, Indian has training facilities committed to seriously perfecting skills of their valued employees. In order to achieve its human resource development objectives, Indian Airlines (as Indian previously known to the world) established its own Management Training Centre (MTC) for executive development This paper is an attempt by the authors to analyse the HRD initiatives of our national domestic carrier, Indian to enhance the competencies of its employees. The paper also points to the need of the airline to incorporate the spirit of HRD in its day today functioning by embracing the all possible human resource systems and mechanisms to the organization.

\section{Introduction}

Human resources are the vital resources of an organization. They form the pivotal role in every activity of the organization. The success of an organization therefore depends to a large extent on their efficiency and effectiveness. Human resource is thought of as "the knowledge, skills, creative abilities, talents and inpuis of an organization's work force as well as the values and attitudes of an individual involved. It is the sum total of inherent abilities, acquired knowledge and skills represented by talents and aptitudes of employed persons. At the organizational level the goal of HRD is normally to have competent and motivated people (employees) to ensure higher levels of productivity, profitability and growth of the organization. Organizations normally direct their efforts towards the development of competencies, culture and commitment among employees individually or in groups. Organizations use many mechanisms to achieve HRD goals, as without competent and committed employees, organizations can achieve very little even if they have excellent technological and other resource bases.

Globalisation intensified the competition among tourism enterprises and resulted in the emergence of a knowledge-based economy. The knowledge-based economy utilizes the skills of the workforce to the full and prompts new ways of thinking about Human Resource Development (HRD) by organizations. This has placed a great demand for specialized competencies and value added services from the employees in these tourism organizations. The major changes in the 
tourism environment have also increased the significance of HRD. It is only the human asset, which can improve the standards of tourism industry and may continue to meet the challenges of globalization and deregulations. HRD is critical in tourism industry because of the similarity among the intangible products and services offered by similar tourism enterprises. It can only be differentiated by its services and professionalism. It is the calibre of the human resource that makes difference between an average and superlative tourism experience. Training has a central role to perform and in carving new competencies. Without the positive HRD activities, it would be difficult for tourism enterprises to stay alive in the fast changing world. The penetration of technology has demanded different skills and competencies on behalf of employees and also impacted upon education and training needs. The emergence of 'new tourist' also has implication for HRD. The more discerning and experienced consumers demand higher quality tourism products and services. In such a situation only the organizations capable of creating a competitive edge can continue their achievements. The only way to reach such competitive edge in field is through Human Resource Development. In the last two decades Human Resource Development (HRD) has come a long way. Liberalization of the economy and its improvement towards globalization has brought in new challenges for Indian business in terms of business strategies, technology, quality concerns; cost effectiveness, management systems etc. All these have brought new challenges for the human resource function. As a result HRD has emerged as a business necessity of the time. HRD is a process which aims at helping people to acquire competencies such as knowledge, skills, dynamism, initiation, attitudes etc. and the process of acquisition can be facilitated by HRD instruments like performance appraisal, training, OD, feedback and counseling, career development, potential development, job rotation and rewards.

\section{Multiple Goals of HRD}

Human Resource Development is a continuous process to ensure the development of employee competencies, dynamism, motivation and effectiveness in a systematic and planned way. HRD has multiple goals. This includes employee competency development, employee motivation development and organizational climate development. Employees require a variety of competencies (knowledge, attitudes, and skills in technical areas, managerial areas, behavioral and human relations areas and conceptual areas.) to perform different tasks or functions required by their jobs. The nature of job is constantly changing due to changes in the environment, changes in organizational priorities, goals and strategies, changes in the profiles of fellow employees (subordinates, bosses, colleagues etc.), changes in technology, new opportunities, new challenges, new knowledge base etc. Such a change in the nature of jobs require continuous development 
of employee competencies to perform the job well. HRD aims at constantly assessing the competency requirements of different individuals to perform the jobs assigned to them effectively, and provide opportunities for developing these competencies. HRD also aims at preparing people for performing roles, jobs, tasks, functions which they may be required to perform in the future as they go up in the organizational hierarchy. Other goals of HRD are to develop and maintain a high motivation level of the employees, strengthen team spirit among different teams, strengthen superior-subordinate relationships, promote interteam collaboration and to promote climate development and organizational health development.

\section{HRD in Tourism Sector:}

Tourism is a high touch, high tech, high involvement industry where it is the people who makes the difference. The quality of human resources in tourism will allow enterprises to give a competitive edge and deliver added value with their service. Excellence in service can only be achieved by people. By developing individuals and deprived groups through various learning experiences in a definite time period, the job performance in an organization could be improved. The increasing significance of human resource development, in service organizations is very well realized by the airline industry in India.

Airline industry is a business of people (staff) providing services to people (customers) who share these senvices with other people (fellow passengers). These services are intangible, perishable, variable and inseparable in nature. The production and consumption of these services are carried out simultaneously. It is here that the HRD is expected to play a crucial role in airline industry to cope with the challenges of advancement in technology, changing markets, industry restructuring and more competitive domestic and international business environment.. The ability to succeed will depend largely upon the skills, qualities and knowledge that managers will be able to bring into their business.

Till 1990 the public sector Indian Airlines had the monopoly over Indian skies. In 1990 as a result of 'Open Sky Policy'. of government of India, domestic airline industry became more competitive with the participation of private airlines like Jet Airways, Air Sahara etc. In the era of globalization and information technology, the trends in airline industry will be to increase employee motivation, and thus assure retention and qualitative service quality. The emergence of a more discerning and experienced customer is demanding higher quality products and service. The performance failure in an airline may be largely due to human failure. It is the human resources that create organization and make them survive, 
grow and excel. Airline Industry has to be very selective both in terms of recruitment, selection, orientation training, supervision and motivation. If the HRD policies and practices are poor, the survival of airlines will be in danger. The impact of deregulation of airlines, changes in technology, globalization and events like September 11, 2001 had lead to drastic changes in human resource development policies and practices of public and private domestic airlines in India. Productivity per employee and the employee ratio to provide services, compensation etc. in Indian domestic airline industry is quite varied in nature. The second phase of open sky policy saw the emergence of low cost airlines and the international operations of certain domestic airlines flying abroad. Still ahead the consolidation of private airlines will mark the coming days. It is in this background the public sector Indian Airlines is trying to change its blurred image by changing its logo and renaming it to Indian to woo the dynamic new age passengers. Indian has already taken a series of HRD initiative to meet the challenges of airline industry.

\section{HRD Initiatives of Indian}

Airline business demand, unique and intensive training of its personnel for service excellence. Effective management of delivery process helps to differentiate an ordinary and excellent airline. To achieve the status of an excellent airline, Indian has training facilities committed to seriously perfecting skills of their valued employees. The central training facility of the airline is responsible for coordinating technical training on all key company areas; ground operation, reservation, inflight service system, flight operation and maintenance. Indian has taken efforts to impart communication and leadership skills, professional development and personal development of its valued employees.

The Central Training Establishment (CTE) at Hyderabad is the best-equipped facility of its kind in South Asian Region since its inception in 1958. The establishment has developed into an internationally acclaimed epicenter for training of all aspects of Civil Aviation. CTE has been conceived and is being developed like a university devoted to civil aviation and air transportation. CTE, therefore, attempts to use all facilities relating to training in the field of aviation management within a single campus. The CTE continues to extend the infrastructure facilities for training demands of external agencies, airlines and private candidates apart from fulfilling the training commitments of Indian and Alliance Air.

Following up gradation of ILS system in December, 1999 at Delhi, CTE conducted low visibility training for pilots covering all pilots on A320/A 300 aircraft, CAT II/ CAT III and TCAS programmes were conducted. 
Core competence and infrastructure facilities at CTE helped Indian Airlines' (IA) participation and supportive roles in organizing "Flight Simulator Approval Course" under the aegis of Director General Civil Aviation (India), Airbus Industries, France, other airlines in India and abroad and with the help of $\mathrm{C}_{0}$ operative Development of Operational Safety and Continuing Airworthiness(COSCAP) of South Asia(April 2000).

Following the hijack of Indian Airlines Airbus A300 aircraft (IC-814 on 24th Dec 1999), seminars were held for senior pilots, flight safety officers and faculty members of CTE to develop special/integrated training module for future which incorporates and focuses on "Role of Human Factors in improving Aviation safety". Under the guidance of Bureau of Civil Aviation Security, special training programmes were held in which IA participated, covering nearly 400 pilots of Indian Airlines and Alliance Air to highlight handling in crisis situations, human factors, safety devices. These were later incorporated/emphasized in the Training Manual.

The employees of Indian could be classified under two categories:

A. Executives: Pilots, Engineers, Flight engineer and General Category are the executive category employees

B. Non Executive Category: includes line pilots, ground instructors, Cabin crew; Air Craft Engineer technical and non technical staff and others.

The Human resource activities of Indian are as follows:

1. Management training schemes for newly recruited management trainees through campuses and open competitions.

2. Organizes induction programmes for other newly recruited officers and trainee pilots etc.

3. Organizes Orientation programme for newly promoted Assistant Managers (IFS), a new cadre officers.

4. Organizes Management Development programmes for newly promoted officers and assistant managers from within.

Conducts executive development programmes for Senior Executives.

Functional programmes, Awareness programmes, Seminars for specific category of personnel are other major Human resource Development highlights of Indian. 
Human Resource Development Objectives of the Management Training Centre (MTC) is stated below:

$>$ To develop present capabilities of the Human Resources for better and effective delivery

$>$ To develop competencies of its manpower, so as to attain world class standards and to meet future challenges.

$>$ To identify and further individual potential and create inter departmental synergy to achieve organizational goal

$>$ To create a mindset for accepting and adapting to changes.

In order to achieve its human resource development objectives, Indian Airlines (as Indian previously known to the world) established its own Management Training Centre (MTC) for executive development. It was initially functioning at Safdar Jung Airport, New Delhi. Later it was shifted to the Central Training Establishment of Indian at Hyderabad.

MTC organizes and conducts a range of Human Resource Development programmes for its personnel. Various categories and programmes are mentioned below.

a) Management Development Programme (MDP):

Two weeks Junior Management programme for officers, who promoted from within, executive development programme for station managers and general management programmes are also organized under MDP.

b) Functional Programme: Functional Programme in Personnel, Finance, Stores and Purchases, Sales, Public Relations, Security, Vigilance and In-flight services are the major programmes under this category.

c) Induction and Orientation Programme: It is for the officers who are directly recruited, particularly for officers in specialized category.

d) Management Trainee Programme: This is a comprehensive orientation cum induction training plan for 6 months for the directly recruited candidates, who are essentially placed as Assistant Managers in various departments.

e) Programmes on Soft Skills: It includes programmes designed for conflict management, beyond team building, effective communication skills, interactive skills, Leadership, motivation, problem solving etc. 
f) Special Programmes/Seminars: Conducted includes the business management workshop for Senior Executives, constructive sales planning programmes, effective trade union management, SC/ST/OBC policy guidelines for members of the association and officers, and staff in personal departments, Aviation security training etc.

g) Other Programmes: MTC organizes other programmes like, actionable strategies, Aviation Scenario for executive Cabin Crew, disinvestment awareness, TQM and ISO 9000 etc.

Following table give details of training targets achieved by Indian at MTC, Hyderabad as per the Memorandum of Settlement signed between Indian and the Ministry of Civil Aviation.

Training Targets achieved by MTC

\begin{tabular}{|c|c|c|}
\hline Year & $\begin{array}{c}\text { Actual No. of Employees } \\
\text { Trained }\end{array}$ & Target for Excellence \\
\hline $1994-95$ & 5045 & 6000 \\
\hline $1995-96$ & 5128 & 5000 \\
\hline $1996-97$ & 10967 & 6000 \\
\hline $1997-98$ & 10355 & 8000 \\
\hline $1998-99$ & 7090 & 4600 \\
\hline $1999-2000$ & 6092 & 5100 \\
\hline $2000-2001$ & 6250 & 5600 \\
\hline $2001-2002$ & 8282 & 5600 \\
\hline $2002-2003$ & 7136 & 5600 \\
\hline
\end{tabular}

*Source: MTC, Hyderabad

The above table clearly indicates, Indian had taken lots of measures by organizing training programmes for all categories of employees and strives for fulfilling the HRD objectives of Indian. 
No. of Managers/Executives Trained at MTC

\begin{tabular}{|cc|}
\hline Year & Total Participants \\
\hline $1997-98$ & 1334 \\
\hline $1998-99$ & 1637 \\
\hline $1999-2000$ & 1724 \\
\hline $2000-2001$ & 1208 \\
\hline $2001-2002$ & 910 \\
\hline $2002-2003$ & 788 \\
\hline
\end{tabular}

**Source: MTC, Hyderabad

The above programmes are either offered by Internal Faculty of MTC Hyderabad or with the help of external experts. For example the Customer Service workshop for Front Line Officers and staff of commercial department was offered by AMITY Business School, Delhi and Internal Audit Workshop for Internal Audit Department was conducted by Internal and External faculty.

\section{Commercial Training College}

On Indian Airlines getting Quality Accreditation for ISO 9002 from the Registrar of Accreditation (RAB) of USA, the commercial training college conducted revised Basic Dangerous Goods programmes to cover all the cargo personnel of Indian Airlines.

\section{The Ground Support Training School}

Organizes special programmes for Plant/Ground support officials/technicians for ramp equipment operations and maintenance apart from functional training courses for operators and drivers.

\section{The Cabin Crew Training School}

Conducts induction courses for the Cabin crew, in addition to Refresher courses of all Senior Cabin Crew. Rajbhasha section spearheaded CTE's contribution for implementation of official language policy. 
The role of employee in the airline business dictates the training needs. Pilots, cabin crew and security personnel requires training largely focusing on the technical nitty-gritty, which is infact the basic requirement of their jobs. The role in in-flight staff demands initial training in customer service, grooming, safety, emergency procedures and first aid. Reservation personnel are trained on specific softare, which serves as central reservation system. The ground staff or frontline employees in reservations, ticketing, and customer care and traffic assistants have constant interaction with passengers. Though technical inputs are mandatory to a large extent because of constant customer interface soft skills are equally critical in airline industry. Hence much emphasis is given to frame modules aimed at team building, leadership skills, communication skills and situational analysis as evident from the HRD initiatives of Indian.

\section{Conclusion}

The above discussion on the HRD initiatives of public sector domestic airline of our nation Indian gives an insight in to the HRD policies and practices of Indian to gain competitive edge in the fast changing environment in airline industry. The paper also points to the need of the airline to incorporate the spirit of HRD in its day to day functioning by embracing the all possible human resource systems and mechanisms to the organization.

\section{References:}

1. Rao, Subba P, Human Resource Development Policies in Public Enterprises- Emerging Trends, Personnel Today,Oct-Dec 1988.

2. Venkateswaran, K.P.S, Evolution of Human Resource Development, Personnel Today, Jan-Mar, 1993.

3. Mehta, Jehangir, Carving Crew Competencies, Human Capital, October, 2002.

4. Rao, T.V, Human Resource Development: Experiences, Interventions, Strategies, Sage Publications, New Delhi, Edn. 2005.

5. Rao, T.V. Future of HRD, MacMillan India Ltd.Edn. 2004

6. Rao, T.V.The HRD Missionary, Oxford \& IBH Pub Co. Ltd, New Delhi Edn. 2000.

7. Gittell, Jody Hoffer, The South West airlines WAY, Tata McGraw-Hill, New Delhi, Edn. 2004 www.indian-airlines. nic.in 